\title{
STRUCTURAL ANALYSIS OF THE PROPERTY: OPTIMUM PRINCIPLE
}

\begin{abstract}
The article presents structural analysis of property in terms of its two basic elements: public and private property. Much attention is given to the criteria of efficiency estimation of functioning of these property kinds, and to expediency substantiation of privatization and property nationalization. The optimum principle of property structure in economic system is suggested. Proceeding from substantiation of theoretical criteria of privatization and nationalization in the economy, general mistakes and consequences of privatization in transitive economies are analyzed on the example of Russian economic system. The basic institutions of business activity are examined in the article demonstrating the model of the state as an entrepreneur which deals with privatization and nationalization at a certain period of time. Basic principles and evaluation indicators of effectiveness and management of the process of "state business" are worked out.
\end{abstract}

Key words: institutions, property, structure, privatization, nationalization, efficiency criteria, optimum principle, business activity, government

\section{Entrepreneurship in Economy and Economics}

Both entrepreneurship as a concept of economics and entrepreneurship as a process in the economy have a determining function in these spheres. In economics it is due to the fact that entrepreneurship is a major property of market economy. This kind of activity and its entities has become the object of analysis and theoretical generalization [1-3, 8]. We may think of I. Kirzner's almost classical objections concerning J. Schumpeter's view that business activity breaks market equilibrium because an entrepreneur initiates economy changes and creates new possibilities, or, according to J. Schumpeter, "new combinations" [8]. In other words, entrepreneur's activity, whether he is an innovator or not, take economic system away from equilibrium. On the contrary, I. Kirzner asserted, that entrepreneur plays counterbalancing function in the economy. In other words, his actions result or should result in equilibrium in economic system

Oleg Suharev, Doctor of Economic Sciences, Professor of the Institute of Economy of Russian Academy of Sciences, Moscow, Russia, e-mail: o_sukharev@list.ru. 
[3]. He introduces the term of "counterbalancing changes", and considers the situation with the influence of business activity on the economy as "unavoidably unbalanced" [3, p.77]. If the reason of imbalance is market lack of information, that is, in modern language "information asymmetry" an entrepreneur aspires to overcome this lack of information, to overcome erroneous decisions and to initiate corresponding alterations which will step by step lead the system to balance. The problem of this contrasting is not even in the fact that the analysis is based on the point of equilibrium and the reasons generating it, but in the fact that equilibrium (if to consider aspiration to it or deviation from it) is the result of supply and demand interaction. And only their ratio will define this point both for economy as a whole, and for local markets. It is not enough to consider only a businessman to estimate the volume of supply and demand and their relationship. I. Kirtsner especially singles out not only the creating role of the entrepreneur producing changes (new combinations) and possibilities, but also the role of the person who uses possibilities which are already available, that is, who acts as a certain reagent for them. Economic dynamics provides multiple combination of various factors, so there are reasons deflecting the system from equilibrium, and providing the opposite vector. Though the effect of these reasons in time and strength can be insufficient to return the economic system to equilibrium. The reasons of imbalance are much deeper. They are in the properties of supply and demand, in the strength of preferences and changes in the social standard of consumption, technological possibilities and their flexibility and may little depend on entrepreneurial ability.

Spirit of enterprise is the ability to operate, make decision and to undertake something in any kind of activity to get income (profit). It is a feature of people's character, their psychological mood, perhaps psychological type of an individual, type of motivation, and the conditions in the economy to realize the listed actions and procedures. If there are strong de motivators of agents' economic activity in economic system, there is social apathy or low interest not only to augmentation of one's own income, but also to any actions and efforts in different business spheres. Entrepreneurship becomes the activity with a wandering vector and its potential in influence on economic dynamics will be low enough. Owing to the specified circumstances enterprise activity stylistics and organization of this activity differ from country to country. National psychology, traditions (various kinds of culture), and formal institutions regulating economic field of interactions legislatively influence the type of agents' actions and business strongly. Certainly, initial conditions, resources and initial information availability and level of markets organization on which businessmen operate in search of compensation for their efforts are important. Types of business are also different. Thus, two big types of entrepreneurial activity are singled out: the activity connected with product creation for the purpose of getting profit, and the activity connected with rendering of these or those services, making deals (exchanges) and financial 
speculation. These are called transactional business. In each economic system the structure of these kinds of activity, as well as the possibility of getting profit, differ appreciably enough. Together with the generated risks of enterprise activity of various kinds (from industrial to speculative business), it creates the general background of business development. Reward for the ability to join production factors, to define their most successful combination makes enterprise profit which cannot be reduced to only profit from the used property (factors) as factors compatibility is of basic importance. And it is the entrepreneur who provides this compatibility. In essence, enterprise profit acts as reward (residual and nonpredictable) for psychological decision-making ability, and sometimes for the ability to be in the proper place at proper time. In other words, in some cases it is accidental payment for entrepreneurial abilities. From the point of view of cost estimation of various production factors (capital, land, labour), estimation of entrepreneurial ability to get profit is not the most verified and the gap between original abilities and propensities to business (this ability) and such estimation is the greatest in comparison with other factors. Though, certainly, the factors are very strongly connected. However, at speculative business the factor "management" is weakened, because the entrepreneur aspires to define precisely the moment of cheap purchase and expensive sale. And that is all. He does not connect factors together. In other words, profit here is, in greater degree, the reflection of not only the ability to analyze received information about the market quickly. It depends not only on the entrepreneur. It is more the reflection of the factor of good luck and success, and fundamental conditions defining, for example, the laws of stock exchange functioning, etc.

The major institution and regulator of all kinds of business is the state in the name of the government and regulatory authorities which form necessary institutions creating or eliminating agents' motivational activity. At the same time, the state itself is the agent of entrepreneurial activity which is connected not only with creation of public benefits and provision of them to all the economy agents, but also with specific instrumental actions which have entrepreneurial character. In particular, it is a matter of privatization and nationalization of various assets that makes the basis for the state business. It is this kind of entrepreneurship and a foreshortening of regulation problem of the processes that we will consider further on in the article in details, singling out institutional conditions and the efficiency aspect of management of these processes. Besides, parallels with business in the market of highly technological production which cannot be created without the government will be defined. The process of privatization and nationalization which sets the basic institutions of private and public sector functioning and the necessary stimulus is an important regulating effect of the state on enterprise activity.

Principles of asset management which can be designated as the principles of privatization and nationalization in economic system are of economic value. 


\section{Principles of Asset Management in Public and Private Sectors}

Let's formulate the main principles of privatization in any economic system.

1. Adaptability and adequacy. Privatization plan should include the purposes and problems and estimation of important parametres of privatization (scope, kinds of privatized assets-objects, value of these objects, assets, privatization speed, form, legal foundation, calculation of efficiency criteria - though they have theoretical drawbacks, but nevertheless they give a rough estimate of privatization adequacy). The plan should correspond to adequacy principle, that is, it should be adequate to the problems of economic development and should not reduce the basic parametres of social and economic development and efficiency. It should also correspond to adaptability principle, that is, it should give time lags to agents for them to get used to the changing situation connected with the change of assets possession structure, motivations, wages change, possible unemployment growth (in an ideal it should be eliminated). The necessity of privatization, its scope and speed (adequacy) should be substantiated and measures on damping negative possible manifestations (adaptability), for example, rejection by employed population are suggested.

2. Re currency. This principle postulates possibility to change privatization vector and the matter, up to cancellation of privatization of some objects, if unpredictable costs (transformational and transactional) sharply and unexpectedly increase. Besides, the re currency principle should mean, that privatization can be reconsidered or cancelled by the state if legal violations are revealed in the course of its carrying out. Models of such cancellation demand special working out, but now the very statement of necessity of such schemes corresponding to the principle of recurrency of actions is important.

3. Adjustment. This principle means that the price of the asset being sold or sale conditions can be changed or the state will keep a certain control over the assets during its subsequent exploitation. Or the list of privatized assets can be changed, and nationalization list is introduced. By the way, in case when some assets to be privatized are unnecessary for the state, but other kinds of property to be nationalized are extremely necessary, the adjustment principle means calculation of equivalence of the sums which should be obtained from privatization of one assets (property) to get other assets as state property. Thereby, adjustment of property and assets structure will be provided. That is why this principle is designated as adjustment principle.

4. Planned recoupment. It is the principle of stage-by-stage evaluation of costs and incomes and financial stabilization. To fulfill this principle it is necessary to use design solution methods of poorly structured problems of planning and management, and to use the criteria of project recoupment (financial criteria are presented below). 
5. Safety. It is the principle of adherence of economic and military and technical of the state security. Privatization should not worsen the parameters of economic and military and technical security and strengthen the negative externalities referred to of military security.

6. Principle of institutional planning. This principle includes several principles which we will show below and it is the major condition of efficient control of privatization and nationalization process.

The following ones will be referred to such principles and they will have continuous numbering ${ }^{1}$.

7. The principle of setting the objective. Institutional planning is a set of administrative procedures, the execution of which is a special task of the government though individual economic agents can be engaged in it - firms, large corporations, associations, public organizations, unions, and etc. First of all, it is necessary to define the purposes of institution planning and to get a general idea about desirable or undesirable state of the economy. Secondly, it is necessary to analyze, how well the planning body understands the available social problems and whether there exist institutional possibilities of their settlement. Besides, it is necessary to formulate some purposes to distinguish the declarative, unrealizable purposes from really achievable ones. Thirdly, it is required to develop some variants of institution design which, according to the planner, are capable to achieve the objective (objectives). Fourthly, it is required to generate criteria of institutions selection and to carry out comparative analysis of different variants on the basis of resource provision and limitation of time. Fifthly, it is necessary to choose the variant (institution) and to adapt it to the conditions of economic environment. Besides, it is especially necessary to define the possibilities of introduction of new institutions in the mode of "borrowing", that is, being oriented on the experience of the rules in other social and economic system (effectiveness from functioning).

8. The principle of defining application area. Before designing (creating) an institution, it is necessary to define what niche in economic structure it will occupy. This niche is application area of a specific institution. Formal institutional structures can be global, that is, they can extend influence on economy as a whole, or they can be local, they influence strictly on certain groups of economic agents. This gradation allows singling out accurately the area of application of the designed and introduced institution. But it is not enough for defining the area of institution application. It is required to define its actual position in the economic structure into which the given institute is introduced and to get all the characteristics of the object of institutional transformations to foresee the possible changes of these parametres in the best or in the worst way. As the designer has several variants of institution it will be required to carry out comparative analysis

Sukharev O. S. (2001): The Theory of Economic Dysfunction. Mashinostroeniye (Machine Building), Moscow. 
to find out the most productive institutional form. Actually, it is necessary to analyze the parametres of application area and adjacent areas of future institutions and then to carry out their joining and "implantation" of new institution.

9. The principle of functional completeness. This principle allows answering the question: what will institution do in its niche and what functions will or will not it carry out? Besides, it is important to understand, what functions should and should not be carried out. There arises the problem of measure, completeness of functions and institutional adequacy here. Functions arise on the basis of what actions should be carried out, what agents are involved in the new scheme of interaction, what operations are carried out at that, what problems are solved, what are the changes and what incomes and costs are. The quantity of functions should not surpass a certain admissible limit. Otherwise there arises an institution dysfunction at the stage of its designing. However, it should not be small as then the expenses for creation of this institution won't be justified. Each institution has a mission to execute a certain set of functions. If the rule is introduced, but it does not cover its functional area, the costs exceed benefits and there is a typical "investment trap", the main characteristic of which is unjustifiedness of means (resources) investments.

10. The principle of requisite variety. Actions of agents are extremely various. Institutions structure this variety, making them to act within the limits of the established rules. The known rule from cybernetics says: the system keeps stability, if the variety of managing group is not less than the variety of managed object. Hence, institutional matrix should come to conformity with the matrix of individual actions. In other words, the variety of action and institutions models should not differ strongly though it is impossible to achieve exact coincidence.

11. The principle of necessary perception. At institutional planning it is necessary to act on the premise that subjects (enterprises) and agents do not accept new institutions, they reject them often enough. If the number of such institutions is great enough, economic system can start to degrade and the rate of this process will be defined by the intensity of rejection of introduced rules. Hence, adjustment of former structures to expected innovations should become one of the planning problems.

12. The principle of stability to changes. Institution stability to changes is programmed by strict observance of the first five principles and the seventh one. Instability is a vivid sign of institution dysfunction and is expressed in appearance of deviant forms of behaviour, non-obedience to the established rules and opportunism.

13. The principle of monetary support. Institutions cannot function without cash security. If institutions are not provided with money, it will be impossible to organize any effective work of current institutions and, all the more, newly created ones. Privatization also demands expenses, it changes the structure of assets, creates new rules of privatization and motivation carrying out, and, 
hence, the new rules or mental models of players' behaviour in the market. So, it is necessary to take this aspect into account, as efficiency of privatization and further functioning of changed property will depend on how monetary streams are distributed according to the assets structure.

Non-observance of one of the principles is fraught with appearance of dysfunction of organization, institution, process and action as the objects of institutional planning. In other words, inefficiency can be installed at the planning stage due to the infringement of the principles of institutional planning.

More than once supporting application of the designing approach in economy and in economic science, I can confirm its utility in the analysis of privatization and nationalization, and, what is especially important, in management of privatization and nationalization. Designing assumes substantiated choice of priorities and alternative variants with a definitive reasoning of one variant which can be updated and corrected in the course of its implementation. The plan and the project can include such activity right away. It is an immanent principle of planning and designing. Today nobody sets abstract objectives and priorities. Behind each purpose and priority there is a project or a development program. The problem here is that there can be tens of such projects even on privatization. And a priori efficiency is a seeming efficiency, non-registering conditions and state of a certain subsystem or economy as a whole. Such efficiency appears to be rather relative. Any projects are realized within the framework of the main directions which are subject to selection, as well as the projects. The same refers to privatization and nationalization which can be presented as a certain project covering either all the economic system, or its separate sectors. Priorities are definitely important here, and nobody chooses them in abstracto any longer.

Today the private property structure in developed economy changes quickly enough due to financial markets and share market, where various share holdings are repeatedly resold. The state also buys and sells securities, shares, in particular, as it is a co-owner of the state-private companies. However, if there is management inefficiency in the public sector where the enterprises are entirely in the state property (defensive sector, for example), no guarantee of efficient control, as well as automatic effective influence of the state can be expected as the state has only some share holding of the enterprise. Everything is defined by operational efficiency, including the human factor and the management level representing both purely private company, and the state.

If a certain asset can be sold with income $\mathrm{D}_{c}$ to the owner (the owner was the state during privatization), it is important to compare this income plus discounted value (standard of discount $\mathrm{i}(\mathrm{t})$ - time function) of tax earnings $(\mathrm{N}(\mathrm{t}))$ for a certain subsequent period of time [t1, t2], and the amount of the discounted income $(\mathrm{d}(\mathrm{t})$ ) for the same period which would have been received by the proprietor (state) if it had not sold this asset (income together with the tax component). From the purely financial point of view, if the left part of the 
inequality surpasses the right one, then privatization is justified. We will write down this criterion in the following way:

$$
D_{c}+\int_{i 1}^{t 2} \frac{N(t)}{(1+i(t))^{t}} d t>\int_{i 1}^{t 2} \frac{d(t)}{(1+i(t))^{t}} d t
$$

It is possible to present the similar logic so:

$$
D_{c}+\sum_{i=1}^{T} \frac{N_{i}}{(1+\alpha)^{i}}>\sum_{i=1}^{T} \frac{d_{i}}{(1+\alpha)^{i}},
$$

where: $\alpha$ - standard of discount; $\mathrm{T}$ - the general interval of time during which the value of one and another income is compared, $i$ - an intermediate elementary interval of time during which there are data concerning the received income.

The private owner will be interested in the purchase of the property from the state, bearing expenses for this purchase $\mathrm{D}_{c}$. For the state it is revenue earned if the obtained asset during the period [t1, t2] allows getting income $\mathrm{D}_{\mathrm{p}}$ (from privatized asset) minus taxes, this pure discounted income being more than the expenses of the private owner $\mathrm{D}_{c}$. In other words, the purchase will take place for the private owner participating in purchase of the state property if the following financial criterion is fulfilled:

$$
\int_{t 1}^{t 2} \frac{D_{p}(t)-N(t)}{(1+i(t))^{t}} d t>D_{c}
$$

Thus, privatization is expedient, if the discounted income obtained by the private owner from privatized asset in the given interval of time should be above the discounted income which the state would have in the same interval of time if the asset was all this time in its property. The danger of use of such financial criteria is in the fact, that the more is the interval of time which is approaching to the service life of an asset, the more is the probability that the income in the private sector will be larger than the available one. Thereby there appears absolutely incorrect substantiation resulting supposedly from the fact that in the long run the private sector will provide higher efficiency, than the public sector. However, thus relation and mutual influence of various kinds of assets in changed structure during the process of privatization are not considered. It is possible to argue similarly in the case of nationalization as well.

If we introduce the price of asset unit $\mathrm{p}$, and asset value $\mathrm{Q}$, then privatization is possible at the price (cost estimation of asset being sold):

$$
p>\frac{1}{Q} \int_{t 1}^{t 2} \frac{d(t)-N(t)}{(1+i(t))^{t}} d t
$$


The problem is in how to estimate the time interval during which the state received income from the asset, when it was at its disposal, and tax revenues when the asset was sold to the private owner. Time interval can be estimated according to the operational period of the asset. But change of discount standard is a more complicated task. After its sale to the private proprietor the asset can change its previous type, and a can part of it is modified, or lost during operational process by the private owner. And such solution can be used either just after privatization, or in some foreseeable period of time. On the other hand, the private owner can increase the asset for a certain period of time, and the increased asset will give more tax revenues. But how can the outcome be forecasted? It is the most complicated task of economic analysis of privatization as a process. There are similar questions concerning nationalization. However, the argument that the owner can do whatever he likes with his property does not work concerning state ownership, as what is profitable to the government, officials and bureaucratic system does not mean that it is profitable to the people representing the given state, that is, society as a whole. Social effects of privatization should also be considered. They should be additional and not less important criteria of its efficiency estimation, as well as the efficiency estimation of nationalization. If you owned asset $Q$ and decided to sell the asset in volume $\alpha \mathrm{Q}$, where $\alpha$ - a share of asset being sold from the available amount, you still have asset $\mathrm{q}=\mathrm{Q}-\alpha \mathrm{Q}=\left(\begin{array}{l}1 \\ \alpha\end{array}\right) \backslash \mathrm{Q}$. At each subsequent stage of privatization it is important to define value $\alpha$, that is, the amount of asset which needs to be sold at a certain price. And the government ought to estimate the demand for such assets and how the situation will change in the market of the given asset. With reference to nationalization it is not necessary to estimate such demand, because nationalization problem is absolutely contrary, in comparison with privatization. Nationalization can be voluntary when the private owner himself wishes to sell a part or the whole property, or compulsory when the state forces the owner to do so or actually expropriates the property with allowance for waste to the owner. The power mechanism is necessary to return the engaged bureaucratic decisions and to counteract corruption in privatization generated by the desire of bureaucracy to enrich itself for the account of the state property. The intensity of privatization process can be estimated as $\mathrm{q}_{\mathrm{t}} / \mathrm{q}_{\mathrm{t}-\mathrm{i}}$ for all equal time intervals $\mathrm{t}$ on privatization interval, and $\mathrm{q}$ in this case is a volume of asset which is available at the moment of time $t$ and the previous moment $(t-1)$.

The situation when the state sells a part of property is possible, and the rest part starts to bring greater income, than all the property till this moment. At any rate, such situation is possible, at least, theoretically. In this case, the criterion changes, the probability of decision-making in favour of privatization sharply increasing. 


\section{The Necessity of Structural Analysis of Property and Formations of Privatization and Nationalization Criteria}

Economists often use expressions "rational property structure" or "optimum structure" concerning the problems of transitive economic systems. However, usually there are no comments, what this or that term means, whether to consider rational property structure as a synonym of effective structure or not and what optimum structure means. What is the criterion of optimality or rationality? Besides, there is a problem of use of such concepts as "quality of public administration" and "market quality". A priori, according to the principle of "a thumb" a certain criterion, absolutely standard, not following from the logic of the analysis is set, that, say, privatization is defined by the quality of public administration and market quality. It is possible to object, that the majority of criteria are set normatively. And it is true. But, in this case, connection with the quality concept becomes relative as management quality should be defined. Otherwise, it is impossible to say which quality is higher, and which one is low. How is management quality connected with its efficiency? Should more efficient management be automatically considered qualitative, than less efficient one? And what are the parametres measuring quality and efficiency of public administration? It is even more difficult to use the concept of "market quality". To introduce the criterion with the meaning that efficiency (success) of privatization is defined by the market quality, means, firstly, to be able to define this quality and measure it. Secondly, it would be required to estimate the quality of various markets, instead of one abstract aggregated market. Thus, if we introduce a certain indicator of such quality estimation, the quality of separate markets can be high, and it can be low for some others. If we follow this standard criterion for "poor-quality" markets, it should limit privatization at once 2 .

I consider such logic ungrounded and vague as privatization can solve the problem of improvement of market quality for the account of competition stimulation or redistributions of assets which are sold by the state to the private owners. The problem is that theoretically it is impossible to unite or join the conclusions concerning the quality of public administration and market quality. If the country is transitive, that is, it carries out the transition from centralism to the market economy, the markets quality is probably low or there is no quality at all as many markets do not exist yet. It is possible to consider the quality of public administration as low because the state is controlled centrally and from the positions of public sector management in the economy of markets. It is a different way of management, and its quality is different, too. For convenience, it is possible to consider it even as poor quality. Then, proceeding from the stated above, privatization is impossible. Therefore researchers, who so easily use the

Coase R. H. (2010): The Firma. The Market. The Law. Delo, Moscow. 
principles and criteria of controlled processes which are the objects of their study, come to incorrect conclusions.

Assets being privatized are different. They possess specific properties and characteristics. Some part of assets can and should be a concern of privatization in a given period of time. And each kind of asset is intended for further operation in the private sector and serves one, two or several markets, the state of which also differs, that is, quality here is also different and cannot serve a uniform criterion. Besides, privatization purpose may be the problem of structure and quality change of a certain market.

Certainly, both quality of public administration and markets quality have some influence on privatization and nationalization. However, this quality is defined by a compound set of institutions, including the rules of privatization and nationalization themselves. General efficiency of application of these tools in aggregate and individually depends on designing of these rules and corresponding laws describing the possibilities of two tools of management of property structure in the economy.

Transactional and transformational efficiency of these institutions will also define privatization and nationalization efficiency. Low efficiency of public administration will hardly result in effective privatization or nationalization. In turn specified tools I can be perceived, as actions capable to change efficiency of the government towards increase. However, such outcome is not guaranteed.

Privatization, as well as nationalization, always leads to redistribution of assets, that is, to their restructuring. Therefore, both tools should be considered as structural measures. In this connection, the problem statement about effective (optimum) structure of the property and criteria of such optimality is quite justified. Certainly, re distributional and restructuring effect depends on privatization and nationalization matter, their scale, speed and conditions. But it is always present. There are ensuing individual consequences on the labour market in each separate case.

Following Coarse's tradition ${ }^{3}$ to suggest the starting point of analysis, which has trivial formulation, and afterwards attach great importance to them, D. Sappington and J. Stiglitz ${ }^{4}$ expressed opinion, that if information is symmetric, the agents are neutral to risk and there is pure competition (large number of sellers and buyers, homogeneous goods) in the property market ${ }^{5}$, privatization leads to effective solution of the problem of property use. In the case, when the

Veblen T. (2007): Theory of Business Enterprise. Delo, Moscow.

Sappington D., Stiglitz J. (1987):“Privatization, Information and Incentives”, Journal of Political Analysis and Management, Vol. 6, № 4, 567-582.

5 It is a fantastic assumption because even with great negative allowance there never exists homogeneous property which is subject to sale - privatization. In this market there cannot be a great number of sellers as privatization is carried out by the government. And the number of buyers is also limited due to the size of the sold property and its cost. Budgetary restrictions here are rather strong. 
named criteria are broken, privatization cannot lead to effective result. However, here again the researchers bypass the question concerning effective solution: what to consider and what efficiency criterion to build into the basis of analysis. In practice, there are risks considerable enough. Information is asymmetric, and, of course, there is no model of pure competition in the property market. Hence, conditions for inefficiency are present, though three specified criteria can be essential for the analysis of privatization productivity, but they are not sufficient in any way. Besides, nationalization and its efficiency demand other criteria. It was discussed above.

Thus, the point of view of Sappington-Stiglitz actually proclaims unimportance of patterns of ownership when they set the conditions themselves ${ }^{6}$. Almost as well as efficiency and production pattern do not depend on distribution of ownership of Coarse- Stigler ${ }^{7}$ if conventional-lifeless restrictions are introduced. So, a peculiar zero point is set. Around this point there are problems whose sharpness is excessively overestimated, as the original complexity of problems is connected with the fact that economic systems were never and will never be in such points. There are no such conditions. It means that it is absurd to formulate such combination for them, considering it a peak of intellectual achievement.

\section{Optimum Principle of the Property Structure and Criteria of Privatization and Nationalization Expediency}

Now let's designate possible criteria, when privatization or nationalization is expedient, and the optimum principle of the property structure in the economy (one of the possible ones) [2].

Let's introduce the following parametres: $\mathrm{Q}_{\mathrm{p}}, \mathrm{Q}_{\mathrm{g}}$ - value of private and public property accordingly (cost estimation), $\mathrm{D}_{\mathrm{p}}, \mathrm{D}_{\mathrm{g}}$ - value of the added cost created with the use of private and public property (or in private and public sector), $I_{p}$, $I_{g}$ - investments in private and public sector (or in an increment of private and public property), $\mathrm{Q}$ - the whole volume of the property (assets of the public and private sectors), $r_{p}, r_{g}$ - profitability of investments in private and public sectors, $\alpha, \beta$ - shares of private and public property accordingly in the total amount of property, the sum is equal to unity. To be exact privatization function should be equal not to the share of private property as such, but to change of this share in time, that is, $\alpha=\mathrm{f}(\mathrm{t})$ ). And the change itself will make privatization minus augmentation of private property as a result of economic growth. However, we will build our analysis on the change of a share of private and public property

$6 \quad$ Sappington D., Stiglitz J. “Privatization, Information and Incentives”, Journal of Political Analysis and Management, Vol. 6, №4, 567-582.

7 Veblen T. (2007): Theory of Business Enterprise. Delo, Moscow. 
not to complicate the computation. It is clear, that if we have the share change, the scale of privatization and nationalization in time is quite definable. Then it is possible to introduce the following correlations:

$$
\begin{aligned}
& \mathrm{Q}=\mathrm{Q}_{\mathrm{p}}+\mathrm{Q}_{\mathrm{g}} \\
& \left.\mathrm{Q}_{\mathrm{p}}=\mathrm{a} \mathrm{Q} \text { (Privatization function } \alpha=\mathrm{f}(\mathrm{t})\right) \\
& \left.\mathrm{Q}_{\mathrm{g}}=\beta \mathrm{Q} \text { (Nationalization function } \beta=\mathrm{f}(\mathrm{t})\right) \\
& \mathrm{r}_{\mathrm{p}}=\mathrm{D}_{\mathrm{p}} / \mathrm{I}_{\mathrm{p}} \\
& \mathrm{r}_{\mathrm{g}}=\mathrm{D}_{\mathrm{g}} / \mathrm{I}_{\mathrm{g}} \\
& \mathrm{r} \mathrm{1}=\mathrm{D}_{\mathrm{g}} / \mathrm{Q}_{\mathrm{g}} \\
& \mathrm{r} 2=\mathrm{D}_{\mathrm{p}} / \mathrm{Q}_{\mathrm{p}} \\
& \chi=\mathrm{Q}_{\mathrm{g}} / \mathrm{Q}_{\mathrm{p}} \text { (Property structure) } \\
& \gamma=\mathrm{D}_{\mathrm{g}} / \mathrm{D}_{\mathrm{p}} \\
& \eta=\mathrm{I}_{\mathrm{g}} / \mathrm{I}_{\mathrm{p}} \\
& \chi=\beta / \alpha \\
& \mathrm{Q}_{\mathrm{p}}=\alpha \mathrm{Q}_{\mathrm{g}} /(1 \alpha) \\
& \mathrm{r}_{\mathrm{g}}=\gamma \mathrm{r}_{\mathrm{p}} / \eta \\
& \mathrm{Q}_{\mathrm{g}}=\chi \mathrm{Q}_{\mathrm{p}}
\end{aligned}
$$

Using the cited correlations it is possible to make a decision on privatization and nationalization as on the whole on the economic system, so on each kind of asset individually. The following parametres are useful for the analysis: $\gamma, \chi, \eta, r_{p}$, $r_{g}, r 1, r 2$. Parametres $r=f(t)$, characterize investments efficiency in public and private sector, and the general efficiency of public and private property.

If the value added created in the public sector (on the basis of state property) is less than the value added created in the private sector $(\gamma<1)$, profitability of investments is also less in the public sector in comparison with the private one $\left(r_{g}<r_{p}\right)$, general efficiency of the property is also less $r 1<r 2$. Then at $\chi \geq$ 1 privatization expediency is high as the value of state property excels private property. And vice versa, when $\chi<1$, nationalization is most probable. Though, I would not separate these two processes. Both procedures can be used simultaneously on different assets, at least, theoretically. And practically there are no serious obstacles for this.

Having written down the key condition as follows:

$$
\begin{aligned}
& \frac{r 1}{r 2}<1, \chi \geq 1 \text { - Privatization } \\
& \frac{r 1}{r 2}<1, \chi<1 \text { - Nationalization }
\end{aligned}
$$

Having substituted expressions for $\mathrm{r} 1$ and $\mathrm{r} 2$ and having made substitutions to express a (t), we'll get: 


$$
\begin{aligned}
& \gamma<\chi \\
& \alpha<\frac{1}{1+\gamma}
\end{aligned}
$$

In other words, correlation of the values added in the public and private sectors should be less, than correlation of the values of the public and private properties with the efficiency not in favour of public sector (profitability correlation). Parametre $a(t)$ should be less than the expression in the right part of the inequality $1 /[1+\gamma(\mathrm{t})]$.

Thus, at

$$
\begin{aligned}
& \chi \geq 1 \\
& \gamma<\chi \\
& \alpha<\frac{1}{1+\gamma}
\end{aligned}
$$

privatization is possible.

And at

$$
\begin{aligned}
& \chi<1 \\
& \gamma<\chi \\
& \alpha<\frac{1}{1+\gamma} \quad \text { nationalization is possible. }
\end{aligned}
$$

If profitability correlation is in favour of the public sector in comparison with the private one, that is, the state property is more effective according to the criterion $\mathrm{rl} / \mathrm{r} 2 \geq 1$, then, at $\chi \geq 1$ privatization is more probable to support private sector. Or the decision depends on additional correlations $\gamma, r_{p}, r_{g}$, that is, both privatization and nationalization are possible, depending on these additional parametres. At $\chi<1$ - nationalization is more possible.

The optimum property structure can be set with the criterion of maximization of the value added per unit of the value of public and private properties created on its base. In other words, it is possible to write down the following for each sector (kind of property):

$$
\begin{aligned}
& r 1=\frac{D_{g}}{Q_{g}} \rightarrow \max , \\
& r 2=\frac{D_{p}}{Q_{p}} \rightarrow \max
\end{aligned}
$$

Considering the total volume of property $\mathrm{Q}$ in the economy on the interval of privatization and nationalization invariable, having carried out the necessary substitutions, and taking a derivative $\mathrm{dr}_{\mathrm{i}} / \mathrm{dt}$, from the first criterion for $\mathrm{rl}$ we will have: 


$$
\frac{d \alpha(t)}{d t}=\alpha(t) \frac{1}{D_{p}(t)} \frac{d D_{p}}{d t}
$$

The second criterion $\mathrm{r} 2$ will give the following correlation:

$$
\frac{d \alpha(t)}{d t}=-\beta(t) \frac{1}{D_{g}(t)} \frac{d D_{g}}{d t}
$$

Thus, the growth rate of the private sector is proportional to the share of this sector in the economy, where proportionality coefficient is the relation of rate of change of the value added to its value (an increment of the value added). On the other hand, the rate of change of the share of the private sector is proportional to the share of public sector with a negative sign, where the proportionality coefficient is an increment of the value added in the public sector. The negative sign means that during privatization one sector is decreasing and the other is increasing for the account of the reduction of the first one. Certainly, the general tendency of economic growth can change this correlation, providing growth of both sectors. In this case, when the derivatives are taken, value $\mathrm{Q}$ should not be considered constant $(\mathrm{Q}=$ const). Then, taking a derivative we will get:

$$
\frac{d \alpha(t)}{d t}=\alpha(t)\left[\frac{1}{D_{p}(t)} \frac{d D_{p}}{d t}-\frac{1}{Q(t)} \frac{d Q(t)}{d t}\right]
$$

And it is necessary to notice, that

$$
\begin{aligned}
& \frac{d r 1(t)}{d t}>0, t<t 0 \\
& \frac{d r 1(t)}{d t}<0, t>t 0
\end{aligned}
$$

where $t 0$ is a point in which there is the extreme of function $a(t)$.

As a hypothesis, it turns out, that the general growth of the value added in the private sector favours privatization, and the general economic growth reduces the necessity of privatization.

If we substitute value $\chi Q_{p}=\chi \propto Q$ in the second criterion for $r 2$, and defining $\mathrm{Q}=$ const, it is possible to receive the expression for the increment of public sector share $\beta(t)$ depending on the increment of investments profitability in the public sector, correlation of investments in the public and private sectors and increments of private investments:

$$
\frac{1}{\beta(t)} \frac{d \beta(t)}{d t}=\frac{1}{r_{g}(t)} \frac{d r_{g}(t)}{d t}+\frac{1}{\eta(t)} \frac{d \eta(t)}{d t}+\frac{1}{I_{p}(t)} \frac{d I_{p}(t)}{d t}
$$


And here using the received correlation the restriction concerns the function $\mathrm{r} 2(\mathrm{t})$ in order to receive maximum on criterion $\mathrm{r} 2=\mathrm{D}_{\mathrm{p}} / \mathrm{Q}_{\mathrm{p}} \rightarrow \max$ :

$$
\begin{aligned}
& \frac{d r 2(t)}{d t}>0, t<t 0 \\
& \frac{d r 2(t)}{d t}<0, t>t 0
\end{aligned}
$$

The optimum property structure will be set by parametre $\chi=\beta / \alpha$. Having defined values $\beta$ and $\alpha$ for the point where there is maximum of the established criterion $\mathrm{r} 1$ and $\mathrm{r} 2$, we will get optimum property structure for the given economic system at a certain interval (moment) of time. Having substituted necessary sizes we will receive:

$$
\begin{aligned}
& \chi=\frac{D_{g}(t)}{D_{p}(t)}\left[\frac{d D_{p}(t)}{d t} / \frac{d D_{g}(t)}{d t}\right] ; \\
& \chi=\gamma\left[\frac{d D_{p}(t)}{d t} / \frac{d D_{g}(t)}{d t}\right]
\end{aligned}
$$

At $\mathrm{D}_{\mathrm{p}}^{*}$ and $\mathrm{D}_{\mathrm{g}}^{*}$ which correspond to the extreme point the optimum property structure according to the given criterion $(\beta / \alpha)$ will be achieved. It is important to notice, that optimum structure depends on many factors. It is defined by both initial distribution of property, sectors profitability, and by privatization and nationalization process. If prospective costs of both privatization and nationalization are more than the expected benefits, both processes are inexpedient. Though costs are hypothetical here, that is, they are expected as well as benefits. And the time period, during which they are estimated or can be estimated, is important. As we can see, initial profitableness of kinds of property (assets) will strongly affect privatization and nationalization and the scale of public and private sector. It is important to note quite different thing. For example, there are objects of infrastructure, the construction of which demands much time and capital investments, but financial cover of expenditure lasts decades and is not obvious while calculating. However, the construction of such objects is necessary proceeding from the strategic positions of development and life organization. This refers to the objects of energy, power and resources supply.

Property structure cannot be considered stable, if the costs of privatization and nationalization are higher than the benefits even if they can be estimated precisely. The property as a kind of asset wears out in use. Specific conditions of use of separate kinds of property and their purpose within the framework of public and private sectors can change. Yes, these changes can be less scaled than privatization and nationalization, however, they should not be neglected. Moreover, the value added created in both sectors cannot provide maximum according to the considered criterion. Though the problem of economic science 
and the theories describing the problems of property and privatization is in the fact, that it is impossible to stop on the criterion. Our criterion can also be criticized, however, its utility is in its presence as the presence of some strict criterion is better, than its absence, or presence of several rather conventional criteria, even from the terminological point of view. For example, when both terms, "rational structure" and "optimum property structure", are used.

Rational structure is reasonably substantiated property structure and the most expedient one if to proceed from the meaning of the word "rational". And optimum structure is the most favourable or the best structure from all the possible ones. In other words, rational property structure is a suitable, acceptable structure, but not the optimum one. As to the optimum structure, it is a certain unique and the best structure. Some structures of assets (property) distribution between the owners can be rational, and all the same the optimum structure is a unique structure.

The only thing is quite clear, that both definitions assume the presence of the criterion, which serves the estimation basis of acceptability, expediency of the property structure, as well as the consideration about the best structure variant from the set of possible alternatives. By the way, there may be not a unique criterion in defining rational and optimum property structure, as there are various forms of ownership with their efficiency. Besides, the alternative of property use and its efficiency can depend on the owner within the limits of one and the same form. The criteria can be both quantitative and qualitative. Certainly, the major criterion is asset profitableness, its profitability.

It is also necessary to differentiate inefficiency of privatization and nationalization from their impossibility. Thus, impossibility results from the basic criterion in the form of identity which is discussed above, when costs on all accounts are higher than all the benefits (again we make a reservation, that it is difficult enough to estimate such values fully), and inefficiency of the processes is a function of numerous factors. If property structure is rational, privatization and nationalization are not necessary and are not carried out. Criteria, when privatization and nationalization are expedient and what the condition is, are specified above. If the structure is irrational, any process is possible, or both processes on different kinds of assets (property) are necessary.

The problem of optimum property structure can be presented from the point of view of "portfolio" theories, elementary models of optimization.

If there is a purpose, that a certain property structure should give the greatest net profit $\mathrm{D}$ (income maximum) of all possible, then at $\mathrm{N}$ - assets number (property) characterized by some efficiency $r_{j}(t)(j=1 \ldots N)$ at the expenses for functioning (investments) of $\mathrm{j}^{\text {th }}$ active $\mathrm{x}_{\mathrm{j}}(\mathrm{t})$ it is possible to present model (I):

$$
\begin{aligned}
& D=\sum_{j=1}^{N} \mu_{j} x_{j} \rightarrow \max , \quad \sum_{j=1}^{N} x_{j} \leq M, \\
& r_{l j} \leq r_{j}(t) \leq r_{2 j}, \text { and } r_{j}(t)=f\left(x_{j}(t)\right) .
\end{aligned}
$$


If such property structure, which would provide the least losses for some acceptable income level, is important, then model (II) will be as follows:

$$
D=x^{T} K x \rightarrow \min
$$

with restrictions: $\sum_{j=1}^{N} x_{j} \leq M, x_{j} \geq 0, \mu^{T} x \geq D_{R}, M_{l j} \leq x_{j}(t) \leq M_{2 j}$,

$$
r_{l j} \leq r_{j}(t) \leq r_{2 j} \text {, and } r_{j}(t)=f\left(x_{j}(t)\right) \text {, }
$$

where: $M$ is the general value of resource (finance) available, $M_{1 j}, M_{2 j}$ - limits of expenses change (investments) $x_{j}(t)$ on each kind of property (asset), $r_{1 j}, r_{2 j}$ limits of the return change, asset (property kind) profitability.

These are elementary models of conventional optimization, the first model assuming strategy of quantitative growth when qualitative features of structure formation of assets (property) are not important. Mobilization development strategy is also within the frameworks of such "philosophy". The second model sets (assumes) the objective of qualitative changes with the account of necessary economizing of resources, paying the main attention to institutional structure which finally predetermines value $r_{j}(t)$ and creates low value of possible losses. Such strategy immanently includes measures for growth inhibition of unreasonable needs. The presented models, though they are simple, allow demonstrating impact and regularities of appearance of new rules, influence of rules and property structure on the rate of economic development. For example, with their help it is possible to consider functioning of the rules regulating the volume of ecological pollution (models of conditional optimization allow increasing and writing down differently the restrictions which define the point of model optimum) and besides to carry out the analysis of what set of reforms is necessary to carry out simultaneously (privatization and/or nationalization), pursuing the aim to achieve some value of total revenue and to define what general risk of loss of national income will be while realizing the measures of governmental policy. Within the "portfolio" transfer of asset (property) from public into private possession changes the value of return, the limits of return change on this kind of asset and even the possible amount of expenses and investments into this asset. That is why the result of optimization on the portfolio will change at once, as initial conditions of optimization and its restrictions change. At the same time, these two ideal models set two trajectories of realization of development strategy of the property structure, the original choice of alternative trajectory being such, that the required trajectory is between the specified ideal variants.

Considering that income and expected losses (risk) have monetary measurement, it is possible to present the model on interval $[0 ; \mathrm{T}]$ as follows: 


$$
\begin{gathered}
P(t)=\sum\left[G_{j}-D_{j}\right]=\sum_{j=1}^{m} \mu_{j} x_{j}-x^{T} K x \rightarrow \max \text { at: } \sum_{j=1}^{m} x_{j} \leq M, \quad \mathrm{x}_{\mathrm{j}} \geq 0, \mathrm{M}_{\mathrm{jj}} \leq \mathrm{x}_{\mathrm{j}}(\mathrm{t}) \leq \mathrm{M}_{2 \mathrm{j}}, \\
\mu^{T} x \geq D_{R}, r_{l j} \leq r_{j}(t) \leq r_{2 j}, r_{j}(t)=f\left(x_{j}(t)\right)=\frac{V_{j}}{x_{j}}, \mu_{j}=\frac{1}{T} \sum_{t=1}^{T} r_{j}(t), \mathrm{K}=\left[\sigma_{\mathrm{ij}}^{2}\right], \\
\sigma_{\mathrm{ij}}^{2}=\frac{1}{T} \sum_{t=1}^{T}\left(\mathrm{r}_{\mathrm{i}}(\mathrm{t})-\mu_{\mathrm{i}}\right)\left(\mathrm{r}_{\mathrm{j}}(\mathrm{t})-\mu_{\mathrm{j}}\right) .
\end{gathered}
$$

where: $x_{i}$ - value of cash security of functioning of $\mathrm{j}^{\text {th }}$ asset (property kind) for some period of time [t $1, \mathrm{t} 2]$;

$\mathrm{M}$ - total amount of monetary resource per unit of time;

$\mathrm{V}_{\mathrm{j}}$ - acquired real income by $\mathrm{j}^{\text {th }}$ asset kind (property) per unit of time;

$r_{j}$ - return value;

$\mu_{j}$ - average return of $j^{\text {th }}$ asset (property kind) on interval [0; $\left.T\right]$, including interval $\left[\mathrm{t}_{1} ; \mathrm{t}_{2}\right]$;

$D_{R}$ - limit of growth of the whole structure can eventually change in connection with wealth augmentation and property concentration. On rather short interval, especially at privatization, planning can be accepted as constant and equal to the planned value of property increment and income.

Then the maximum of function $\mathrm{P}$ will be achieved, when:

$$
\begin{aligned}
& \sum_{j=1}^{N}\left[\frac{\partial \mu_{j}}{\partial t} x_{j}+\frac{\partial x_{j}}{\partial t} \mu_{j}\right] \quad \sum_{i=1}^{N} \sum_{j=1}^{N}\left\{\frac{\partial \sigma_{i j}^{2}}{\partial t} x_{i} x_{j}+\frac{\partial x_{i}}{\partial t} x_{j} \sigma_{i j}^{2}+\frac{\partial x_{j}}{\partial t} x_{i} \sigma_{i j}^{2}\right\}=0,(*) \\
& \frac{\partial \mu_{j}}{\partial t}=\frac{1}{T} \sum_{t=1}^{T} \frac{\partial r_{j}(t)}{\partial t} \frac{\partial r_{j}}{\partial t}=\frac{\partial V_{j}}{\partial t} \frac{1}{x_{j}}-\frac{V_{j}}{x_{j}^{2}} \frac{\partial x_{j}}{\partial t}
\end{aligned}
$$

Having substituted the values for $\mu_{j}$ and $r_{j}$ in the expression $\left(^{*}\right)$, we will have the system of equations $\mathrm{N}$ for $\mathrm{N}$ kinds of assets/properties, solving which, we will receive optimum vector $\mathrm{x}=\left\{\mathrm{x}_{1}, \ldots \mathrm{x}_{\mathrm{N}}\right\}$ of resources distributions on the kinds of assets/property with known restrictions for the search of extremum on differentiable function $\mathrm{P}(\mathrm{t})$. The dynamic interpretation will be exactly the same, only it is required to have the maximum product on each interval $\left[0 ; \mathrm{T}_{1}\right] \ldots$ $\left[\mathrm{T}_{\mathrm{n}-1}, \mathrm{~T}_{\mathrm{n}}\right] . \frac{\partial V_{j}}{\partial t}$ Value will be included into the system, and it is none other than the change of real income generated by the $\mathrm{j}^{\text {th }}$ kind of asset/property.

Such statement activates the problem of investments distribution on property structure at once. To be more precise, the model of dynamics $\mathrm{N}$ of interacting ranges of efficiency/inefficiency is introduced. Each of them represents the $\mathrm{j}^{\text {th }}$ kind of asset/property.

From the point of view of aggregated approach, this problem can be solved in static and dynamic formulation with reference to the portfolio of the property 
presented by three kinds of property: public, private, municipal, and also with the account of greater differentiation and specializations of assets (property). Thus there may be privatization with the increasing volume of private asset. But the thesis concerning change of return, which can or cannot occur from such action (privatization), remains important. The similar reasoning is also true for nationalization, and for carrying out of both actions simultaneously on different kinds of assets, to which there is no ban, neither logic, institutional (legislative), or political. Taking into account the specificity of assets in such models is possible through the system of restrictions (conditions of optimization). Certainly, the distribution problems of the property and its structure change can be solved through modelling of various agents interaction in the frameworks of the agentfocused models, evolutionary models and, that is the most important, models of the games theory. However, for a series of models of such class it is required to consider the influence of the structure change of property on the behavior. Though, the intensity of such influence on different economic systems will depend on the initial point, initial condition of the system (reference point).

"Portfolio" model says that is not important how the right of ownership is realized and even how this right is distributed on agents and how it is unequally realized in practice for each economic system (such institutional qualities are usually not visible in mathematical statements). But it is important what kind of property prevails in the economy, what structure has been formed, and what risk and income are generated by this structure and this kind of property and what income it allows to increase. And what else is very important - how it should be distributed.

Various assets (property kinds) structure allows expecting different income and level of risk (possible loss of income). It is a basic position which is not often considered in economic analysis and all the more at planning and carrying out of different reforms, including privatization and nationalization. The situation which can be called "characteristic point" is possible (point B, Figure 1) in which various assets/properties structures give identical combination of expected income and overall risk of functioning of the structure. Curve I is drawn on the basis of corresponding model of income maximization, and curve II on the basis of the model of risk minimization. In point $B\left(r_{h}, D_{h}\right)$ - intersection of curves, the assets structures are different, and combination of expected income and risk is identical. In this point there is a problem not only of choice of property structure and search of additional efficiency criteria (For example, estimations of structure quality, or public administration efficiency and positive models of market agents which are formed under the influence of this or that property structure. Some authors use the term "market quality", etc.). But, besides, there is a problem to define the demand for privatization and/or nationalization. 
Figure 1: Various Property Structures (Combination of Income and Risk) and "Characteristic Point".

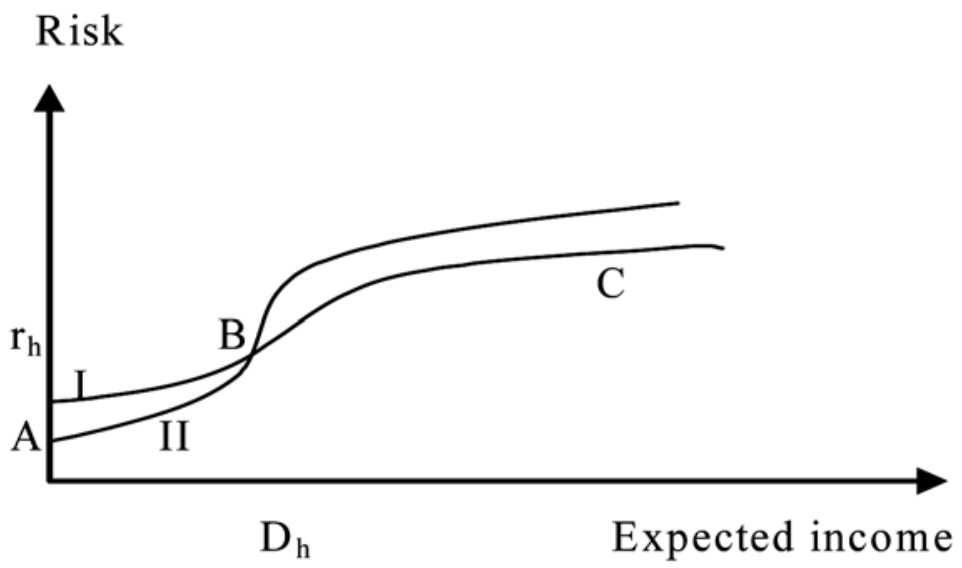

If the economic system moves to point $\mathrm{B}$, or is more to the left of this point, the most acceptable variant of development is branch $A B$, as risk is the least at the same income. Structures, which will give branch above AB, are possible, but it is obligatory below the upper branch $r_{h} B$. However, from point $B$ the further movement along the line $\mathrm{BC}$ is the most acceptable, that is, the assets structure should provide the movement on this branch, or above it, but it should be below line $\mathrm{AB}$ (the part of it that is more to the right of point $\mathrm{B}$ ). Thus, the acceptable envelope symbolizes a set of property structures of ABC. Of course, movement goes on from structure to structure during considerable period of time, privatization and nationalization being considered as the tools providing such movement, that is, changing property structure. Actually, the feature of institutional and structural neutrality of privatization and nationalization is substantiated here, and in wider meaning, institution of "ownership". If to present the transition from one property structure in the economy to the other one as realizable due to the influence of operating factor (privatization and nationalization) plus a certain evolutionary-genetic structure change, then privatization and nationalization are absolutely unproductive in point $\mathrm{B}$, as two structures give the same expected income and risk. In this connection transition from one structure to the other has no motive if not to take into consideration the qualitative aspect and certain criteria (auxiliary) corresponding it, but to proceed only from the criterion of profitableness and risk as the basic rational criteria of economic analysis. In this case, neither privatization, nor nationalization is necessary. In the same point it is not important, how the property right will pass to the state (priority of state ownership and nationalization) or to the private sector (priority of private prop- 
erty and privatization). I proceed from the fact that possession expansion also strengthens the right itself, as an authority system which, of course, cannot vary in content. And their change can lead to the change of possession efficiency and to the change of possession scale that will affect both privatization, and nationalization processes.

Privatization and nationalization have various purposes, functional filling, and tool implementers. Privatization should create possibilities for income augmentation in the economy. Nationalization should solve qualitative management problems of economy structure, fill in missing types of production, technologies, infrastructures, benefits and level differentiation on incomes. By all appearance, nationalization is aimed at quality and structure, on recouping the losses. Privatization is aimed at development rate, quick solution of shortterm and medium-term problems and often the auxiliary problems. Of course, it is not always so. Large-scale privatization, that is, privatization not in the "market economy" pursues an overall aim of transformation of the type of social system. This problem was being solved in the post-Soviet countries.

\section{Privatization in Transitive Economies: Errors and Consequences}

Privatization in transitive economies in 1990-2000s which actually used this instrument for curtailment of centralized planning and organization of markets economy didn't fulfill the specified function, having simultaneously lost its primordial functions, characteristic for privatization in the developed and functioning economy of the markets.

Critical relation to centralized planning depreciated planning function in principle as the function of social and economic system management. During transformations the absence of this function led to infringement of other functions - organization, motivation, control and coordination, with the following general dysfunction of macroeconomic management. It is this aspect that was central in inefficiency of both conducted reforms in whole, provoking deep transitive crisis, and privatization in particular. For the ideological reasons which are in no way connected with the essence of economic analysis, the estimation of nationalization possibility or revaluation of the conducted privatization was not carried out. Competitive economy of the markets didn't arise (when separate markets appeared, control function over them was modified due to many influences including external ones), and planning function was curtailed. Why didn't economy of markets arise? Because this economy is not connected in any way with liquidation of home market, loss of control over it and loss of property. The result of privatization was unfair (unearned) enrichment of one people for the account of others (the model of pure competition of "mainstream" plan does 
not assume such outcomes), de-industrialization and loss of competitiveness, raider captures of property, and etc.

For example, there is still a point of view in Russia that these results must not be reconsidered or nationalization must not be conducted as it may provoke new revolution or shakes of other sort. Certainly, from the point of view of pure theoretical analysis, and practical possibilities as well, this point of view is a usual absurdity. It is another matter, that creative function is more cost-based and long-term in comparison with the destruction function. It is especially seen on the example of evolution of different economic systems in different epochs.

Two processes became the major effects of privatization in the countries of transitive economy. They are: a) liquidation of information function of enterprises, loss of information potential, with the establishment of blocking level on transactional costs for restoration of this level; b) provocation of monopolism level when loss of assets during privatization and "import attack" on home market resulted in either absolute loss of enterprises and production, or in strengthening of the western owners (corporations) in the home market that increased monopolism level on home market and made tangible contribution to maintain high inflation. A special contribution was made by the so-called natural monopolists.

If the costs of privatization and nationalization exceed the profit, that is, the basic identity presented above is not carried out, it means, that the need for carrying out these two processes is absent. However, it does not mean at all, that the property structure is rational or optimum. The criterion of optimum means, that other thing being equal, both kinds of property should provide the greatest possible value of created added cost per unit of cost estimation of the property. Such criterion as it was specified is possible. However, I do not reject introduction of other criteria. The problem of any institutional changes, and it, certainly, concerns privatization and nationalization as versions of institutional changes (the property structure and frequently the behaviour motives vary), is in the fact that while they are not carried out to their logic end, it is problematic to estimate their efficiency. The only thing that is possible to do is to represent the controllable changes on stages, to plan these stages and to estimate intermediate efficiency, proposing to improve some actions and to change the course and trajectory of institutional changes from stage to stage if the movement begins in the direction different from the planned one. However, such management can seldom be observed. May be China demonstrates such management style.

So far as the assets which are in this or that property, are non-homogeneous, costs can generally exceed benefits if they are correctly estimated. But on certain kinds of assets the basic identity can be executed, that is, benefits will be above costs. It is a necessary criterion to carry out privatization or nationalization accordingly, but the criterion is obviously insufficient. It is important to proceed from the criterion of optimum of property structure. Whether the economic 
system will come nearer to this optimum point or it will move off. When costs are discussed, it is necessary to consider costs in full, that is, including negative effects or costs shifted on the third party, which is not participating actually in the course of privatization or nationalization. When benefits are discussed, it is necessary to consider positive externalities. I have already mentioned the complexity of estimation of such costs and benefits.

When privatization is investigated the following mistakes are often made. Such mistakes should not be made in the successive researches and wider estimation problems of privatization and nationalization productivity.

1. Privatization process is presented apart from nationalization process. The opposite orientation of these processes as it has been shown here, is not the basis to consider and apply only this or that process, that is, either privatization, or nationalization, because assets are heterogeneous and property is of various types, specification and state. So, different procedures can be probably applied to such different assets. But in practice some process prevails or only one is really used.

2. Incomparable kinds of efficiency are compared. For example, efficiency of the public and private sectors, or public and private property, one aggregated efficiency criterion being insufficient for estimation of system consequences of activity, privatization and nationalization. It is connected with the assets nature, their heterogeneity and development problems. In reality, it is possible to compare according to only one certain criterion, but who and why establishes one efficiency criteria in efficiency estimation of rather complicated system or economic sector, interacting with the other sector the efficiency of which is also estimated. In this case, at system relation inefficiency of one sector can provide the efficiency of the other one. Such interrelations and possible factors generating them should be considered.

3. Explanation of privatization by "inconsistency of the state", and explanation of nationalization by "market inconsistency" is one more mistake. These concepts demand additional criteria and they are indistinct enough in itself and inexact to make far-reaching conclusions on their basis and especially to make decisions from the point of view of economic system management ${ }^{8}$.

Separation of the created blessings into public and private ones does not also solve the problem. It is considered, that the state has the prerogative to produce only public goods, and the prerogative of the private sector is only private goods. However, what is the demand for the former and the latter? This question is the defining one from the point of view of privatization and nationalization. Production efficiency of public and private goods is different kinds of efficiency if not to compare indicators only according to the resource part. Even carrying out this or that policy the state provides a certain blessing with the fact of its carrying out, for example, it prevents monopolistic effects, slows down inflation, stimulates development of backward regions (for example, due

Kirzner I.M. (2010): Competition and Entrepreneurship. SOTSIUM, Chelyabinsk. 
to climatic features), creates support programs of various branches: agriculture, coal industry, infrastructure, etc., stimulates export orientation of manufacturing activity or import substitution. The major function of the state, defense, cannot be provided without state ownership and public sector. The defense sector includes not only the army and defense facility and the property, but defense enterprises and auxiliary infrastructure. In this sector secret development works are made, new technologies are created assuming considerable volume of investment. Such investments cannot be accumulated by the private owner and he is not interested in such development works. There is no corresponding regime for realization of such works at the private sector. Only the state has the monopoly on them and this public good is strictly supervised legislatively from creation up to storage and use.

4. "Bare" comparisons of the development level of the country according to social indicators and the scale of the public and private sector and connection of the rate of economy growth and the scale of the public sector seem to be limited according to the formulation as the set of other significant factors is not considered. They are inertia system, and the problems of income distribution, the state of productive forces and technologies and the place of the country in the international division of labour, level of competitiveness, and etc. Non-registering these factors it is impossible to draw a certain parallel. The assertion, that in the catching-up countries the public enterprises should play a role of development institutions, and in the leader-countries they should not, is wrong without specifying, what "to catch up" means, and what for to catch up is, whether it is possible, and why private enterprises, for example, large transnational companies do not represent these development institutions. The fairness of this statement is clearly observed according to the changes of today's capitalism where large monopolies define all the world dynamics. Though, the illusion about the importance of small-scale business is persistently supported. The importance of small business, as well as its contribution to economic growth, is, certainly, present, but it can be designated in some different way. Even if different kinds of property make different contribution to the increment of output aggregate, that is, to economic growth, it does not mean, that the kind of property making the smaller contribution should be reduced for the account of privatization or nationalization. Economic growth should be accelerated not by privatization and nationalization, but by the property (assets) structure formed during these processes. It is a basic condition of research and application of these tools. The result of privatization, as well as nationalization should be income created with the use of this property. If privatization and nationalization are held during the limited interval of time which is not so large, the general volume of property does not vary. There is its redistribution, and there is also redistribution of the rights on it with the successive income redistribution. Application of these tools should not be terminated by this redistribution. The important purpose is income increment. 
5. Large private proprietor and the state appoint manager - managing director - for control their property, delegating him the responsibility for the disposal of this asset. The efficiency of management is defined by the functions and powers, certain situation, abilities of the managing director, the executive agents subordinated to the manager, and besides, by motivation and control. It is considered, that the manager operating the property in the private sector has aspired to increase wage or salary which was appointed by the proprietor, and the proprietor aspires to profit maximization, that is, he aspires to increase efficiency of the capital which owns. In the theory this contradiction was called the problem of the "principal-agent" when interests of operating and owning link differ. However, the interest of the managing director in the public sector is also increase of salary, but appointed by the state. Besides, interest in profit increase is possible if the government pays a percent from profit in the form of bonus to managing directors of state enterprises as a stimulating measure for labour. In the private sector managing director affects the proprietor to increase wages, in the public sector managing director affects higher link in the state hierarchy on which wages increase depends on. Or if he has authority, he can increase the bonus from the profit (as a variant). Thus, it is absolutely incorrect to consider, that the problem of the principal-agent does not concern the public sector at all. This problem has other viewpoint here, and the meaning of management doesn't actually change from sector to sector much. Therefore the property efficiency is, of course, stipulated by a set of factors, but it doesn't depend on motivation of managing director, it is more likely defined by the routine of destination and use, that is, a set of problems of higher level connected with operation of this asset.

6. There is also one more mistake. As if when the state sells the enterprises even on "fair" price, that is, having truly estimated their market cost (though such estimation is often misrepresented, to say nothing about the problem of the criterion of true cost) it loses a constant source of incomes. I wrote above, that the former public property which has become private, should bring income to the budget in the form of tax revenues. And it is important to compare these receipts with the income which this asset would have brought (enterprises) if it remained in the public ownership (and it is necessary to discount these values). Losses are not predetermined at privatization. They appear when the strategy of privatization is incorrect and there are mistakes in management. There are no objective losses here and there should not and cannot be. Besides, it is extremely erroneous to consider, that expenses on social program do not pay off. Such statements can be seen in passing in economic literature, but their incorrectness is connected with the criterion introduced for estimation, as such statement is simply estimation from the point of view of the criterion which the researcher uses.

7. The problem of the property cross-ownership when shares of some object, firm or corporation are in the hands of private persons and the state deserves special discussion. The package of ownership defines possibilities to make strategic 
decisions, but also allows direct influence of the state through available share holding on management, approval of the board of directors, and etc. State-private partnership is the form where ownership is mutual, and there are practically no distinctions between the forms of ownership. Besides, today's tendencies of modern capitalism development presuppose almost no borders between the private and public sector that can't but reflect in the change of property structure and its efficiency. Usual criteria here can be not much in use and it is necessary to use the estimations of system efficiency of such joint possession.

Thereby, there are two main approaches to privatization as a process 9 .

Firstly, privatization, as well as nationalization, should be considered as management of property and assets in order to change their structure with the general orientation to change their use efficiency from the point of view of introduced criterion or criteria. Hence, it follows, that efficiency decrease and deterioration of conditions of fair possession are incompatible with the prolongation of the specified processes, privatization and nationalization. Theoretically, both processes can proceed permanently, that is, as long as possible, up to the exhaustion of their main restriction connected with the scale of the public and private property. In practice, from the management position, any process or measure has the purpose which should be quantitatively and qualitatively defined, measurable and there should be a certain time for its achievement. Only thus it is possible to sum up and estimate success or failure of measure undertaken by the government.

Secondly, privatization and nationalization are considered the tools changing the market structure and the level of monopolistic power. Such presentation is also true, as when the assets are bought or sold, there is an additional demand for the property in the property (assets) market. It influences the price and operates in the direction of redistribution of the part of wealth which is embodied in the property, with the successive change of operation profile of these assets. At the same time, it is necessary to understand, that monopoly and "monopolistic effects" are not a market inconsistency (I see the delusion of modern economic theory, even "mainstream". It starts the analysis round the equilibrium point and aspiration to it and considers monopoly as a certain removal from the equilibrium point and competitive market which is somehow recognized effective from the point of view of distribution and use of incomes and resources.). And the form of organization of economic activity plus the form to which competitive market aspires owing to occurrence of surpluses and redistribution of power and incomes.

Moreover, the state possesses absolute monopoly for defense and production necessary for this purpose, including secret ones. It possesses an exclusive right to accept basic legal ordinances, constitutional acts, and the laws resulting from them, and monopoly power to punish for non-observance of these laws, etc. Monopoly has developing science and it allows the science to develop.

Coase R.H. (2010): The Firma. The Market. The Law. Delo, Moscow. 
Monopolistic effects accompany research and development sphere (patents and copyright certificates) and help calculate the price for intellectual achievements and royalties to authors for such work. Large monopoly on microeconomic level is a household as an elementary economic structure where problems of life organization, leisure are solved, time is distributed, including time for child-bearing, education and upbringing, expenses are planned, manufacture process of some kinds of blessings is carried out, and their consumption sometimes overstepping the limits of one family. Monopoly here is connected with the transfer of genetic information, education of children, transfer of the assets obtained by it, and etc. Here effects of property loss, assets augmentation, inheritance, leaving by will, sale of a part property or the whole property and even transfer of some assets in favour of the state or for charitable needs, that is, to the private persons, especially requiring material security are possible.

\section{Literature}

- Veblen T. (2007): Theory of Business Enterprise. Delo, Moscow.

- Coase R.H. (2010): The Firma. The Market. The Law. Delo, Moscow.

- Kirzner I.M. (2010): Competition and Entrepreneuship. SOTSIUM, Chelyabinsk.

- Perez C. (2011): Technological Revolution and Financial Capital. Delo, Moscow.

- Sukharev O. S. (2001): The Theory of Economic Dysfunction. Mashinostroeniye (Machine Building), Moscow

- Sukharev O. S. (2009): The Theory of Economy Efficiency. Finansy I Statistika (Finance and statistics), Moscow.

- Sukharev O. S. (2013): Privatization, Nationalization and Economic Reform. Finansy I Statistika (Finance and statistics), Moscow

- Sappington D., Stiglitz J. "Privatization, Information and Incentives", Journal of Political Analysis and Management, Vol. 6, №4, 567-582.

- Schumpeter J. (2007): Theory of Economic Development. Capitalism, Socialism and Democracy. Eksmo, Moscow.

Paper received: November $7^{\text {th }}, 2014$

Approved for publication: November 21 ${ }^{\text {st }}, 2014$
Rad primljen: 7. novembar 2014. Odobren za štampu: 21. novembar 2014. 
Prof. dr Oleg Sukharev,

Ekonomski Institut Ruske akademije nauka, Moskva, Rusija

\section{STRUKTURNA ANALIZA SVOJINE: PRINCIP OPTIMALNOSTI}

\section{S a ž e t a k}

Rad predstavlja strukturnu analizu svojine u smislu njena dva osnovna elementa: javne i privatne svojine. Mnogo pažnje se posvećuje kriterijumima procene efikasnosti funkcionisanja ovih imovinskih vrsta, kao i svrsishodnosti dokazivanja privatizacije i nacionalizacije imovine. Predlaže se princip optimalnosti strukture imovine u privrednom sistemu. Polazeći od dokazivanja teorijskih kriterijuma privatizacije i nacionalizacije u privredi, analiziraju se opšte greške i posledice privatizacije $\mathrm{u}$ ekonomijama u tranziciji na primeru ruskog ekonomskog sistema. U radu su ispitane osnovne institucije poslovne delatnosti pokazujući model države kao preduzetnika koji se bavi privatizacijom i nacionalizacije u određenom vremenskom periodu. Razrađeni su osnovni principi i pokazatelji procena efikasnosti i upravljanja procesom "državnog posla “.

Ključne reči: institucije, imovina, struktura, privatizacija, nacionalizacija, kriterijumi efikasnosti, optimum principle, poslovna delatnost, vlada 
